\title{
Increased Expression of Lewis $X$ and $Y$ Antigens on the Cell Surface and FUT 4 mRNA during Granzyme B-Induced Jurkat Cell Apoptosis
}

\author{
Yutaro Azuma, * Yoshikazu Kurusu, Hirotaka Sato, Koji Higai, and Kojiro Matsumoto \\ Department of Clinical Chemistry, School of Pharmaceutical Sciences, Toho University; 2-2-1 Miyama, Funabashi, Chiba \\ 274-8510, Japan. ～Received December 19, 2006; accepted January 26, 2007; published online January 26, 2007
}

\begin{abstract}
Cytotoxic $\mathbf{T}$ cells and natural killer cells play key roles in cell-mediated cytotoxicity and can induce apoptosis in virus-infected and malignant cells by releasing cytotoxic granules. In the current study, apoptosis was induced in Jurkat cells, a human $T$ cell line, by delivering granzyme B into the cells using BioPORTER ${ }^{\circledR}$, a cationic lipid formulation. During granzyme B-induced apoptosis, there was an increase in the cell surface expression of Lewis $X$ and $Y$ antigens. To clarify the roles of initiator and executioner caspases in the expression of Lewis $X$ and $Y$ antigens, we treated Jurkat cells with granzyme $B$ in the presence of caspase 3, 8, and 9 inhibitors. The results indicated that delivery of granzyme B into Jurkat cells induces apoptosis by activating caspase 3 and that caspase 3 but not caspase 8 and 9 plays a key role in enhancing the expression of Lewis $X$ and $Y$ antigens. Realtime PCR revealed that expression of the mRNAs for $\alpha 1,3$-fucosyltransferases FUT4 was increased at $3 \mathrm{~h}$ during granzyme B-induced apoptosis, while FUT9 mRNA expression gradually increased after $12 \mathrm{~h}$. This increased expression of FUT4 mRNA occurred downstream of caspase 3 activation and resulted in the increased cell surface expression of Lewis $\mathrm{X}$ and $\mathrm{Y}$ antigens.
\end{abstract}

Key words granzyme B; apoptosis; Lewis X; Lewis Y; caspase 3; fucosyltransferase

Apoptosis, also known as programmed cell death, is a genetically controlled mechanism by which multicellular organisms to regulate normal cell development, tissue homeostasis, and immunological responses. During apoptosis, various cellular events occur, including morphological changes, exposure of phosphatidylserine (PS) on the cell surface, and fragmentation of nuclei. Molecules on the surfaces of apoptotic cells are recognized by macrophages and neighboring resident cells, which then ingest the apoptotic cells via phagocytosis.

Cytotoxic T lymphocytes (CTLs) and natural killer (NK) cells play key roles in the immune response to virus-infected and malignant cells. CTLs and NK cells induce target cell apoptosis through one of two mechanisms ${ }^{1-6)}$ : interaction between Fas ligand on the CTL or NK surface and its receptor on the target cell ${ }^{1-3)}$ and release of cytotoxic granules containing perforin, a pore-forming protein, and granzymes, a family of serine proteases. ${ }^{4-6)}$ Within the granzyme family, granzyme $\mathrm{B}$ is the most powerful proapoptotic protease. Granzyme B can induce target cell apoptosis by cleaving a variety of intracellular proteins, such as procaspase $3,{ }^{7,8)}$ procaspase $8,{ }^{8,9)}$ mitochondrial Bid, ${ }^{10,11)}$ and poly (ADP-ribose) polymerase. ${ }^{12)}$

Perforin or granzyme B alone are not sufficient to induce apoptosis of target cells, and the two appear to work in concert. Specifically, granzyme B must be incorporated into the target cells, and this is mediated by coreleased perforin ${ }^{13)}$ or by receptors on the target cell. ${ }^{14)}$ In in vitro studies, granzyme B has been incorporated into target cells using perforin purified from CTLs or NK cells, ${ }^{15)}$ adenovirus, ${ }^{7,12)}$ or BioPORTER $^{\circledR}$, a cationic lipid formulation. ${ }^{16)}$

In a previous report, ${ }^{17)}$ we showed that during apoptosis in Jurkat cells, a human acute lymphoblastoma cell line, the cell surface expression of the Lewis $\mathrm{X}$ and $\mathrm{Y}$ antigens $(\mathrm{Gal} \beta 1$ 4(Fuc $\alpha 1-3)$ GlcNAc and Fuc $\alpha 1-2$ Gal $\beta 1-4$ (Fuc $\alpha 1-3$ )GlcNAc, respectively) and the expression of mRNA encoding $\alpha 1,3-\mathrm{fu}-$ cosyltransferase (FUT) 4 were up-regulated downstream of caspase 3 activation. In the present study, we induced apopto- sis in Jurkat cells by incorporation of granzyme B using BioPORTER $^{\circledR}$, and we measured the cell surface expression of Lewis $\mathrm{X}$ and $\mathrm{Y}$ antigens and the roles of caspases in their cell surface expression.

\section{MATERIALS AND METHODS}

Materials Recombinant murine granzyme B, RNase A, and propidium iodide were purchased from Sigma Aldrich Co. (St. Louis, MO, U.S.A.). BioPORTER ${ }^{\circledR}$ was obtained from Gene Therapy Systems Inc. (San Diego, CA, U.S.A.). Fluorescein isothiocyanate (FITC)-conjugated annexin V was from MBL Co. (Nagoya, Japan). Anti-Lewis X mouse antibody 73-30 (IgM) and anti-Lewis $\mathrm{Y}$ mouse antibody H18A (IgG3) were purchased from Seikagaku Kogyo Co. (Tokyo, Japan). R-phycoerythrin (PE)-conjugated anti-mouse $\operatorname{IgM}+\operatorname{IgG}+\operatorname{IgA}(\mathrm{H}+\mathrm{L})$ goat antibody (secondary antibody) was obtained from Southern Biotechnology Associates Inc. (Birmingham, AL, U.S.A.). Caspase inhibitors acetyl-AspGlu-Val-Asp-aldehyde (Ac-DEVD-CHO; an inhibitor of caspase 3), acetyl-Ile-Glu-Thr-Asp-aldehyde (Ac-IETD-CHO; an inhibitor of caspase 8), and acetyl-Leu-Glu-His-Glu-aldehyde (Ac-LEHE-CHO; an inhibitor of caspase 9) were obtained from Peptide Institute Inc. (Osaka, Japan). SYBR ${ }^{\circledR}$ Green Realtime PCR Master Mix was obtained from Toyobo Co. (Osaka, Japan). All other chemicals were purchased from Sigma Aldrich Co. (St. Louis, MO, U.S.A.) or Nacalai Tesque (Kyoto, Japan).

Cell Line and Culture Conditions Jurkat cells, which are derived from a human acute lymphoblastoma, were obtained from the American Type Culture Collection (Manassas, VA, U.S.A.) and maintained in RPMI 1640 (Nissui Pharmaceutical Co., Tokyo, Japan) supplemented with 10\% fetal bovine serum (FBS; JRH Biosciences, Lenexa, KS, U.S.A.), $0.3 \mathrm{mg} / \mathrm{ml}$ L-glutamine, $100 \mathrm{U} / \mathrm{ml}$ penicillin, and $100 \mu \mathrm{g} / \mathrm{ml}$ streptomycin at $37^{\circ} \mathrm{C}$ in a humidified atmosphere containing $5 \% \mathrm{CO}_{2}$.

Induction of Apoptosis and Measurement of Cell Via- 
bility Granzyme B was incorporated into Jurkat cells using BioPORTER ${ }^{\circledR}$ according to the manufacturer's protocol. ${ }^{16)}$ Briefly, $2.5 \mu \mathrm{l}$ of BioPORTER ${ }^{\circledR}$ was evaporated to dryness and added by 0 to $44 \mu \mathrm{g}$ of granzyme B in $20 \mu \mathrm{l}$ of $10 \mathrm{~mm}$ HEPES ( $\mathrm{pH} 7.0$ ) containing $150 \mathrm{mmol} / 1 \mathrm{NaCl}$. After allowing the mixture to stand for $10 \mathrm{~min}$ at room temperature, it was mixed with Jurkat cells $\left(1 \times 10^{5}\right.$ cells $)$ in $200 \mu \mathrm{l}$ of protein-free RPMI 1640 and then incubated for $4 \mathrm{~h}$ at $37^{\circ} \mathrm{C}$. After addition of $1 \mathrm{ml}$ of RPMI 1640 supplemented with $10 \%$ FBS, Jurkat cells were further incubated for 0 to $24 \mathrm{~h}$ at $37^{\circ} \mathrm{C}$. For studies of the effect of caspase inhibitors, the Jurkat cells were treated with caspase inhibitors in DMSO (final concentration of $100 \mu \mathrm{mol} / 1$ inhibitor and less than $10 \%$ DMSO) and granzyme B-BioPORTER ${ }^{\circledR}$ complex in protein-free RPMI 1640 and then further incubated in RPMI 1640 containing $10 \%$ FBS. After stimulation, cell viability was estimated using the Trypan blue dye exclusion method.

Flow Cytometry FITC-conjugated annexin V was added to the cell suspensions at a final concentration of $5 \mu \mathrm{g} / \mathrm{ml}$ in binding buffer $(10 \mathrm{mmol} / 1$ HEPES-NaOH, pH 7.4, 140 $\mathrm{mmol} / \mathrm{l} \mathrm{NaCl}$, and $2.5 \mathrm{mmol} / \mathrm{l} \mathrm{CaCl}_{2}$ ) and incubated at room temperature in the dark for $10 \mathrm{~min}$. The cells were washed with binding buffer, resuspended in $10 \mu \mathrm{g} / \mathrm{ml}$ of anti-Lewis $\mathrm{X}$ or anti-Lewis $\mathrm{Y}$ antibody in phosphate-buffered saline containing $1 \%$ bovine serum albumin (1\% BSA/PBS) and placed on an ice for $30 \mathrm{~min}$. The cells were washed twice with $1 \% \mathrm{BSA} / \mathrm{PBS}$ and resuspended in $10 \mu \mathrm{g} / \mathrm{ml}$ PE-conjugated secondary antibody in $1 \% \mathrm{BSA} / \mathrm{PBS}$. After standing on an ice for $30 \mathrm{~min}$ and washing with $1 \% \mathrm{BSA} / \mathrm{PBS}$, stained cells $\left(1 \times 10^{4}\right)$ were analyzed using a CytoACE-300 flow cytometer (JASCO, Tokyo, Japan).

Real-Time PCR for FUTs Total cellular RNA was extracted from Jurkat cells $\left(1 \times 10^{7}\right)$ using RNA Bee ${ }^{\mathrm{TM}}$ (Tel-Test Inc., Friendswood, TX, U.S.A.), and the first-strand cDNA $(20 \mu \mathrm{l})$ was prepared from total RNA $(4 \mu \mathrm{g})$ using a Super Script $^{\mathrm{TM}}$ First-Strand Synthesis System (Invitrogen Co., Carlsbad, CA, U.S.A.), followed by treatment with RNase $\mathrm{H}$ (2 U) according to the manufacturer's instructions. A 5- $\mu 1$ sample of the cDNA was analyzed by quantitative real-time PCR using SYBR ${ }^{\circledR}$ Green Realtime PCR Master Mix (Toyobo) and an ABI Prism 7000 Detection system (Applied Biosystems, Foster, CA, U.S.A.) according to the manufacturer's instructions. The reaction was carried out in a 96-well plate containing $3.5 \mu \mathrm{l}$ of standard plasmid or cDNA, $17.5 \mu \mathrm{l}$ of $2 \times$ SYBR-Green PCR Master Mix, $0.35 \mu \mathrm{l}$ of both forward and reverse primers $(50 \mu \mathrm{mol} / 1)$, and $13.3 \mu \mathrm{l}$ of distilled water. Real-time PCR for FUT1, FUT3, FUT6, and GAPDH was conducted as follows: $50^{\circ} \mathrm{C}$ for $2 \mathrm{~min}, 95^{\circ} \mathrm{C}$ for $10 \mathrm{~min}$, and 40 cycles of $95^{\circ} \mathrm{C}$ for $15 \mathrm{~s}, 60^{\circ} \mathrm{C}$ for $15 \mathrm{~s}$, and $72^{\circ} \mathrm{C}$ for $45 \mathrm{~s}$. Real-time PCR for FUT2, FUT4, and FUT9 was conducted as follows: $50^{\circ} \mathrm{C}$ for $2 \mathrm{~min}, 95^{\circ} \mathrm{C}$ for $10 \mathrm{~min}, 2$ cycles of $95^{\circ} \mathrm{C}$ for $1 \mathrm{~min}, 70^{\circ} \mathrm{C}$ for $1 \mathrm{~min}$, and $72^{\circ} \mathrm{C}$ for $1 \mathrm{~min}, 2$ cycles of $95^{\circ} \mathrm{C}$ for $1 \mathrm{~min}, 67^{\circ} \mathrm{C}$ for $1 \mathrm{~min}$, and $72^{\circ} \mathrm{C}$ for 1 min, and 2 cycles of $95^{\circ} \mathrm{C}$ for $1 \mathrm{~min}, 64^{\circ} \mathrm{C}$ for $1 \mathrm{~min}$, and 72 ${ }^{\circ} \mathrm{C}$ for $1 \mathrm{~min}$, followed by 40 cycles of $95^{\circ} \mathrm{C}$ for $1 \mathrm{~min}, 62^{\circ} \mathrm{C}$ for $1 \mathrm{~min}$, and $72^{\circ} \mathrm{C}$ for $1 \mathrm{~min}$. The amounts of FUT transcripts were determined and normalized by the GAPDH levels. The specific forward and reverse primers for FUTs and GAPDH were as follows:

FUT1, 5'-TGAGGGATCACTGCCAAAATG-3' (forward) and 5'-TCTTGGCAGTTTATGAGCTTTAAAAA-3' (re- verse); FUT2, 5'-GCTCGCTACAGCTCCCTCAT-3' (forward) and 5'-CGTGGGAGGTGTCAATGTTCT-3' (reverse); FUT3, 5'-GCCGACCGCAAGGTGTAC-3' (forward) and 5' TGACTTAGGGTTGGACATGATATCC-3' (reverse); FUT4, 5'-AAGCCGTTGAGGCGGTTT-3' (forward) and 5' -ACAGTTGTGTATGAGATTTGGAAGCT-3' (reverse); FUT6, 5' CAAAGCCACATCGCATTGAA-3' (forward) and 5'-ATCCCCGTTGCAGAACCA-3' (reverse); FUT9, 5' -TCCCATGCAGTTCTGATCCAT-3' (forward) and 5'-GAAGGGTGGCCTAGCTTGCT-3' (reverse); GAPDH, 5'-CAGCCTCAAGATCATCAGCA-3' (forward) and 5'-ACAGTCTTCTGGGTGGCAGT-3' (reverse). Primers for real-time PCR were designed by Primer Express (Applied Biosystems), and the specificities were ascertained by a BLAST search of the DNA Data Bank of Japan (http://www.ddbj.nig.ac.jp/ welcom-j.html).

\section{RESULTS}

Induction of Apoptosis by Granzyme B in Jurkat Cells To evaluate granzyme B-induced apoptosis in Jurkat cells, Jurkat cells $\left(1 \times 10^{5}\right)$ were pretreated with 0 to $4 \mu \mathrm{g} / \mathrm{ml}$ granzyme B-BioPORTER ${ }^{\circledR}$ complex in protein-free RPMI 1640 for $4 \mathrm{~h}$ at $37^{\circ} \mathrm{C}$ and then incubated in RPMI 1640 containing $10 \% \mathrm{FBS}$ for $24 \mathrm{~h}$ at $37^{\circ} \mathrm{C}$. We examined the cell viability and induction apoptosis by measuring cell surface exposure of phosphatidylserine (PS) (Fig. 1A). Granzyme B caused a dose-dependent decrease in cell viabilities and an increase in exposure of PS on the cell surface, as determined by binding of FITC-conjugated annexin V. These three indicators revealed that apoptosis in Jurkat cells reach plateau by $2 \mu \mathrm{g} / \mathrm{ml}$ granzyme B. BioPORTER ${ }^{\circledR}$ alone did not induce apoptosis in Jurkat cells. We next examined the time course of apoptosis induction by granzyme B. We pretreated Jurkat cells with $2 \mu \mathrm{g} / \mathrm{ml}$ granzyme B for $4 \mathrm{~h}$ and then incubated them for 0 to $24 \mathrm{~h}$ in $10 \%$ FBS containing RPMI 1640. Cell viability and cell surface exposure of PS are shown in Fig. 1B. Following the $4-\mathrm{h}$ treatment with $2 \mu \mathrm{g} / \mathrm{ml}$ granzyme B, cell viability was decreased and cell surface exposure of PS was increased within 3 to $6 \mathrm{~h}$ and reached maximal levels after $12 \mathrm{~h}$.

Effects of Caspase Inhibitors on Granzyme B-Induced Apoptosis in Jurkat Cells To examine the role of the caspase cascade in granzyme B-induced apoptosis, Jurkat cells pretreated for $4 \mathrm{~h}$ with $2 \mu \mathrm{g} / \mathrm{ml}$ granzyme B in the presence of $100 \mu \mathrm{mol} / 1$ of caspase 3,8 , or 9 inhibitor and then incubated for $24 \mathrm{~h}$ in RPMI 1640 containing $10 \%$ FBS and 100 $\mu \mathrm{mol} / 1$ caspase inhibitor. Figure 2 shows the effect of these inhibitors on cell viability and cell surface exposure of PS. The caspase 3 inhibitor prevented the decrease in cell viability caused by granzyme B, whereas the caspase 8 and 9 inhibitors did not affect the cell viability (Fig. 2A). In addition, as shown in Fig. 2B, granzyme B-induced cell surface exposure of PS was abolished by the caspase 3 inhibitor. The caspase 8 inhibitor also partially suppressed the increases in PS exposure, whereas the caspase 9 inhibitor had no effect on PS exposure.

Expression of Lewis $X$ and $Y$ Antigens during Granzyme B-Induced Apoptosis We next examined the cell surface expression of Lewis $\mathrm{X}$ and $\mathrm{Y}$ antigens during granzyme B-induced apoptosis. We pretreated Jurkat cells 
A)
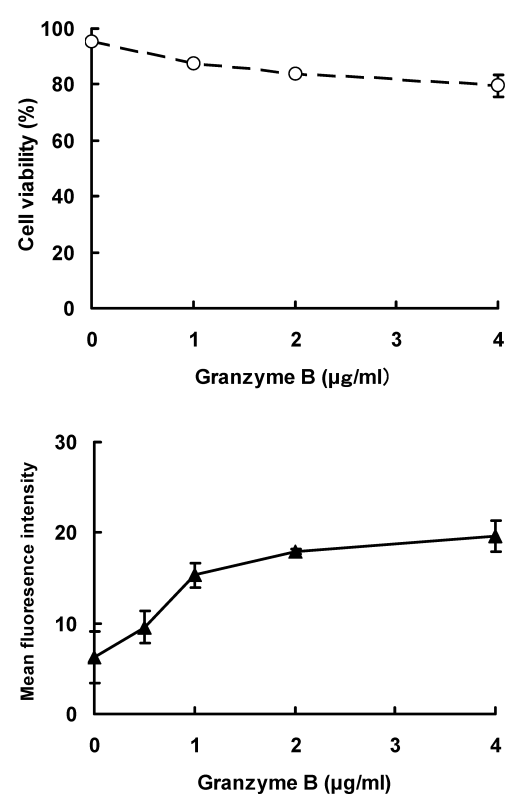

B)
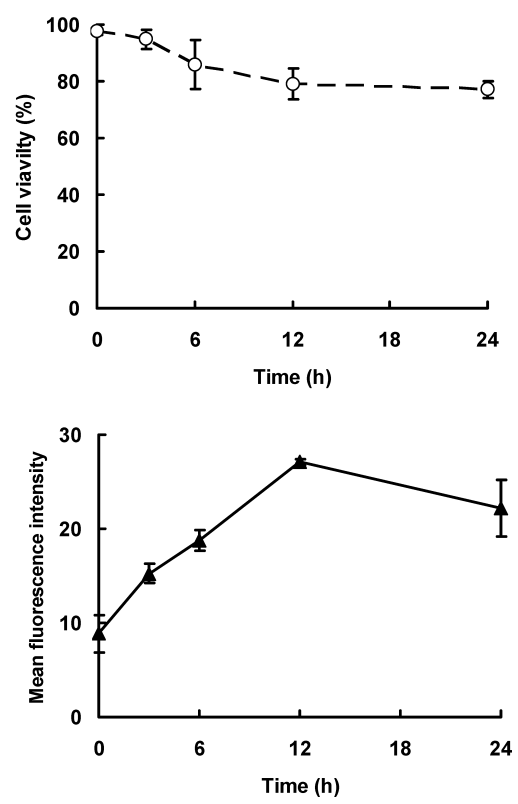

Fig. 1. Granzyme B-Induced Apoptosis in Jurkat Cells

(A) Jurkat cells pretreated with 0 to $4.0 \mu \mathrm{g} / \mathrm{ml}$ granzyme B for $4 \mathrm{~h}$ were further incubated in $10 \% \mathrm{FBS}$ containing RPMI 1640 medium for $24 \mathrm{~h}$ at $37^{\circ} \mathrm{C}$. (B) Jurkat cells pretreated with $2.0 \mu \mathrm{g} / \mathrm{ml}$ granzyme B for $4 \mathrm{~h}$ were further incubated in $10 \% \mathrm{FBS}$ containing RPMI 1640 medium for 0 to $24 \mathrm{~h}$ at $37^{\circ} \mathrm{C}$. Cell viability (upper panel), and cell surface exposure of PS (bottom panel) were analyzed. The results represent the means \pm S.D. $(n=4)$.

A)

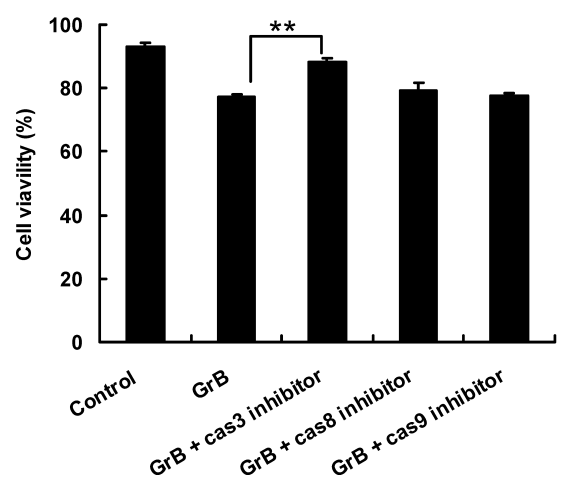

B)

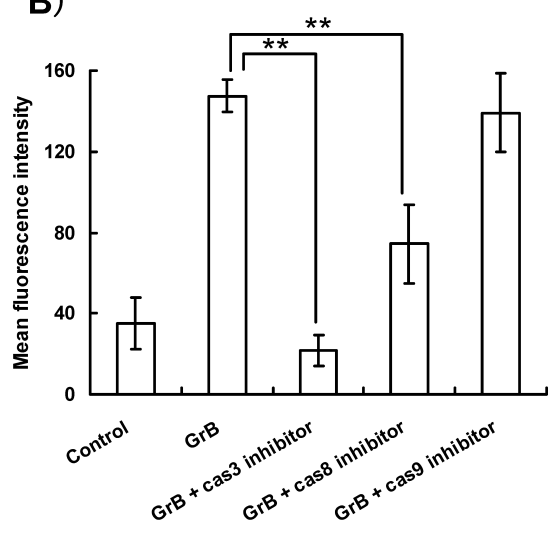

Fig. 2. Effects of Caspase Inhibitors on Granzyme B-Induced Apoptosis in Jurkat Cells

Jurkat cells were pretreated with $2.0 \mu \mathrm{g} / \mathrm{ml}$ granzyme B for $4 \mathrm{~h}$ in the absence or presence of $100 \mu \mathrm{mol} / 1$ of caspase inhibitors and then incubated in medium containing $10 \% \mathrm{FBS}$ for $24 \mathrm{~h}$ at $37^{\circ} \mathrm{C}$. Cell viability (A) and cell surface exposure of PS expression (B) were analyzed. The results represent the means \pm S.D. $(n=6)$. $* * p<0.01$.

$\left(1 \times 10^{5}\right)$ for $4 \mathrm{~h}$ with 0 to $4 \mu \mathrm{g} / \mathrm{ml}$ granzyme $\mathrm{B}$ at $37^{\circ} \mathrm{C}$ and then incubated them for $24 \mathrm{~h}$ at $37^{\circ} \mathrm{C}$. Cell surface expression of Lewis $\mathrm{X}$ and $\mathrm{Y}$ antigens was determined using mouse anti-Lewis $\mathrm{X}$ and $\mathrm{Y}$ antibodies, followed by PE-conjugated secondary antibody (Fig. 3). Granzyme B caused a dose-dependent increase in the expression of Lewis $\mathrm{X}$ and $\mathrm{Y}$ antigens.

To confirm that the increases in the cell surface expression of Lewis $\mathrm{X}$ and $\mathrm{Y}$ antigens were in apoptotic cells, the cells were double-stained for PS and Lewis X or Y antigens using a combination of FITC-conjugated annexin $\mathrm{V}$ and anti-Lewis $\mathrm{X}$ or $\mathrm{Y}$ antibody, followed by PE-conjugated secondary antibody. As shown in Fig. 4, cell surface expression of Lewis $\mathrm{X}$ and $\mathrm{Y}$ antigens was increased specifically on apoptotic cells showing high cell surface exposure of PS. Granzyme B caused a time-dependent increase in these costained cells.

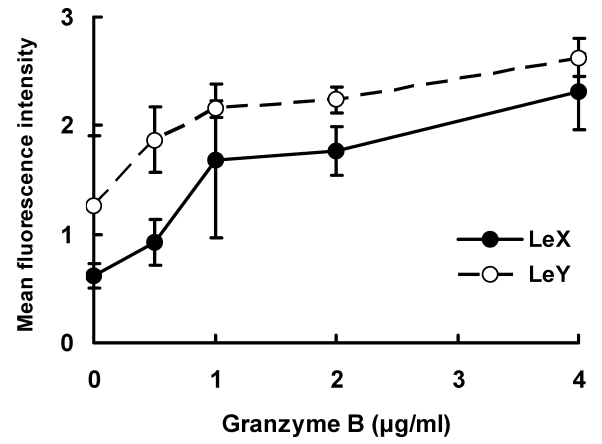

Fig. 3. Cell Surface Expression of Lewis X and Y Antigens on Granzyme B-Treated Jurkat Cells

Jurkat cells were pretreated with 0 to $4.0 \mu \mathrm{g} / \mathrm{ml}$ granzyme B for $4 \mathrm{~h}$ and then incubated in RPMI 1640 containing $10 \%$ FBS for $24 \mathrm{~h}$ at $37^{\circ} \mathrm{C}$. Expression of Lewis X ( and $\mathrm{Y}(\mathrm{O})$ antigens on the cell surface was assessed by flow cytometry. The results represent the means \pm S.D. $(n=3)$. 
$\mathbf{O h}$
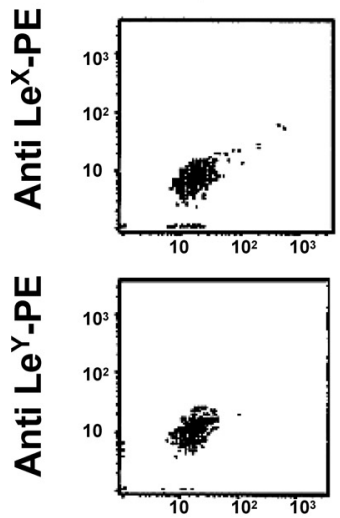

$3 \mathrm{~h}$
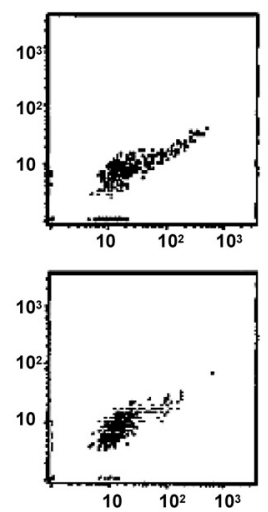

$6 \mathrm{~h}$
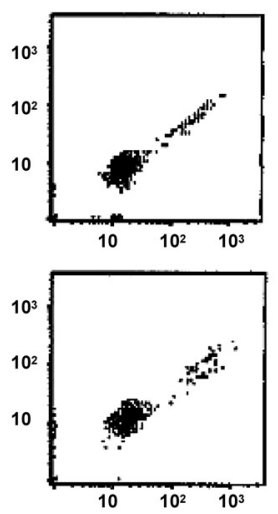

$12 \mathrm{~h}$
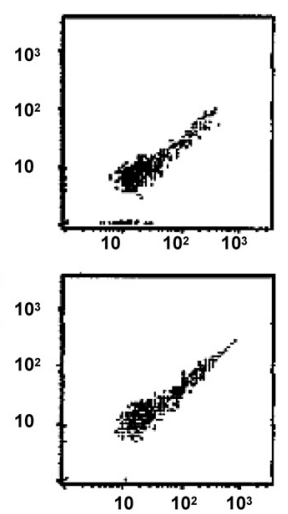

$24 \mathrm{~h}$
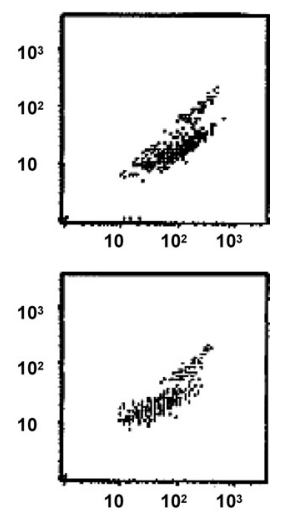

\section{Annexin V-FITC}

Fig. 4. Two-Color Flow Cytometric Analysis for Cell Surface Exposure of PS and Expression of Lewis X and Y on Granzyme B-Treated Jurkat Cells

Jurkat cells were pretreated with $2.0 \mu \mathrm{g} / \mathrm{ml}$ granzyme B for $4 \mathrm{~h}$ and then incubated in RPMI 1640 containing $10 \%$ FBS for 0 to $24 \mathrm{~h}$ at $37{ }^{\circ} \mathrm{C}$. PS and Lewis X and Y antigens expressed on Jurkat cells were stained with FITC-labeled annexin V and anti-Lewis X and Y antibodies, followed by a PE-conjugated secondary antibody. Fluorescence intensities on the cells were analyzed by flow cytometry.

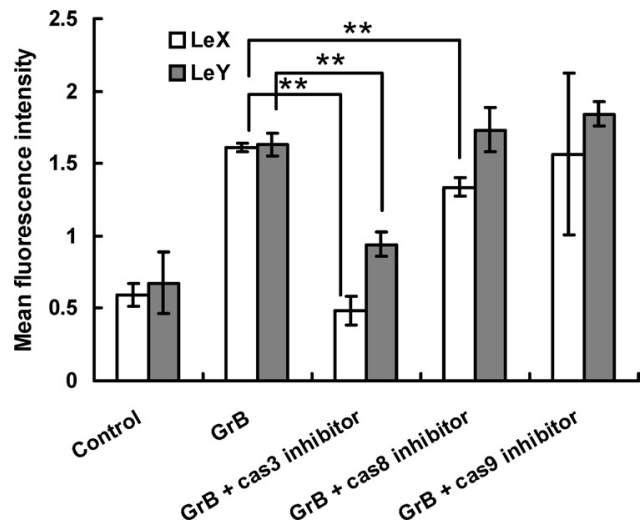

Fig. 5. Effects of Each Caspase Inhibitor on the Expression of Lewis X and Y Antigens on Granzyme B-Treated Jurkat Cells

Jurkat cells were pretreated with $2.0 \mu \mathrm{g} / \mathrm{ml}$ granzyme B for $4 \mathrm{~h}$ in the absence or presence of $100 \mu \mathrm{mol} / 1$ caspase inhibitor and were then incubated in medium containing $10 \% \mathrm{FBS}$ for $24 \mathrm{~h}$ at $37^{\circ} \mathrm{C}$. The cell surface expression of Lewis $\mathrm{X}$ and $\mathrm{Y}$ antigens was measured using anti-Lewis $\mathrm{X}$ and $\mathrm{Y}$ antibodies, followed by a PE-conjugated secondary antibody. The results represent the means \pm S.D. $(n=4) . * * p<0.01$.

Cell surface expression of Lewis $\mathrm{X}$ and $\mathrm{Y}$ antigens was increased within $6 \mathrm{~h}$ following the $4 \mathrm{~h}$ pretreatment with 2 $\mu \mathrm{g} / \mathrm{ml}$ granzyme $\mathrm{B}$; however, this was preceded by the cell surface exposure of PS.

Effects of Caspase Inhibitors on Expression of Lewis X and $Y$ Antigens We also examined the effects of caspase inhibitors on the cell surface expression of Lewis $\mathrm{X}$ and $\mathrm{Y}$ antigens on Jurkat cells. We pretreated the Jurkat cells for $4 \mathrm{~h}$ with $2 \mu \mathrm{g} / \mathrm{ml}$ granzyme B in the presence of $100 \mu \mathrm{mol} / 1$ caspase inhibitor and then incubated them for $24 \mathrm{~h}$ in RPMI 1640 containing $10 \% \mathrm{FBS}$ and $100 \mu \mathrm{mol} / 1$ caspase inhibitor. Figure 5 shows that the caspase 3 inhibitor almost completely suppressed the increase in the cell surface expression of Lewis $\mathrm{X}$ and $\mathrm{Y}$ antigens. In contrast, the caspase 9 inhibitor did not affect cell surface expression of Lewis $X$ and $\mathrm{Y}$ antigens, whereas the caspase 8 inhibitor partially suppressed only the increases in the expression of Lewis $\mathrm{X}$ antigen. Because the caspase 3 inhibitor does not inhibit granzyme B in Jurkat cells (data not shown), the effects of the caspase 3 inhibitor appear to be due to inhibition of caspase 3.

Real-time PCR for FUT mRNAs in Granzyme BTreated Jurkat Cells To investigate whether FUTs may participate in the increased cell surface expression of Lewis $\mathrm{X}$ and $\mathrm{Y}$ antigens during granzyme B-induced apoptosis, we examined the levels of mRNAs for $\alpha 1-2$ FUTs (FUT1 and FUT2) and $\alpha 1-3 / 4$ FUTs (FUT3, FUT4, FUT6, and FUT9) in Jurkat cells pretreated for $4 \mathrm{~h}$ with $2 \mu \mathrm{g} / \mathrm{ml}$ granzyme B and then incubated for 0 to $12 \mathrm{~h}$ with RPMI 1640 medium containing $10 \%$ FBS. The mRNA levels were determined by real-time PCR, normalized by the level of GAPDH mRNA, and compared to the FUT mRNA/GAPDH mRNA ratio in Jurkat cells pretreated for $4 \mathrm{~h}$ with BioPORTER ${ }^{\circledR}$ alone (Fig. 6). Jurkat cells expressed high levels of FUT4 mRNA, moderately expressed FUT1, FUT2, FUT3, and FUT6 mRNAs, and expressed only trace levels of FUT9 mRNA (Fig. 6A). Moreover, the level of FUT4 mRNA was increased within $3 \mathrm{~h}$ in Jurkat cells and strongly increased 6 and $12 \mathrm{~h}$ after the 4-h treatment with granzyme B (15- and 30-fold vs. control, respectively; Fig. 6D). The level of FUT9 mRNA was also increased $12 \mathrm{~h}$ after the 4 -h treatment with granzyme B (15fold $v s$. control), whereas the level of other FUT mRNAs were unaffected by granzyme B (Fig. 6).

\section{DISCUSSION}

In the current study, we examined the expression of Lewis $\mathrm{X}$ and $\mathrm{Y}$ antigens during granzyme $\mathrm{B}$-induced apoptosis and the effects of caspase 3, 8, and 9 inhibitors. The caspase 3 inhibitor was the most effective at inhibiting granzyme B-induced apoptosis. The caspase 8 inhibitor also partially suppressed granzyme B-induced apoptosis, but the caspase 9 inhibitor did not affect either cell viability or cell surface exposure of PS. Increased cell surface expression of Lewis $\mathrm{X}$ and $\mathrm{Y}$ antigens was also induced during granzyme B-induced apoptosis. Double-staining combined with flow cytometry revealed that the increased cell surface expression of Lewis $\mathrm{X}$ and $\mathrm{Y}$ antigens occurred on apoptotic cells. As expected, the increased cell surface expression of Lewis $\mathrm{X}$ and $\mathrm{Y}$ antigens 
(A)

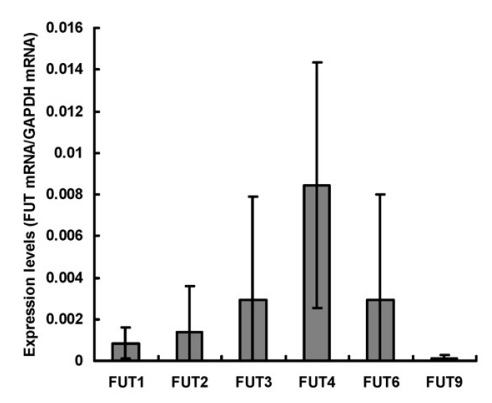

(D)

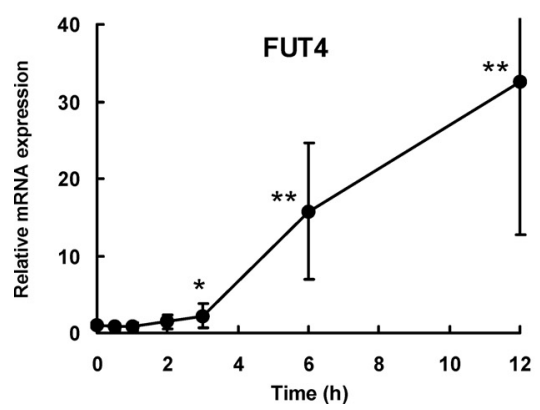

(B)

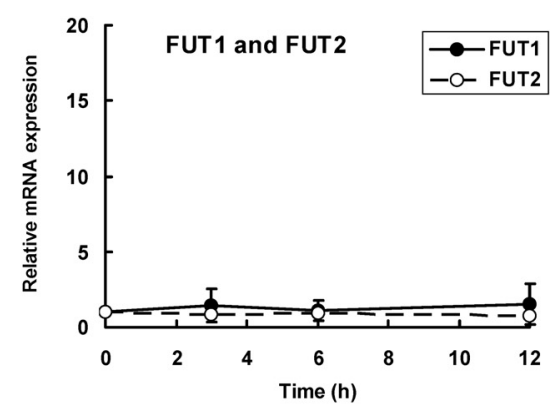

(E)

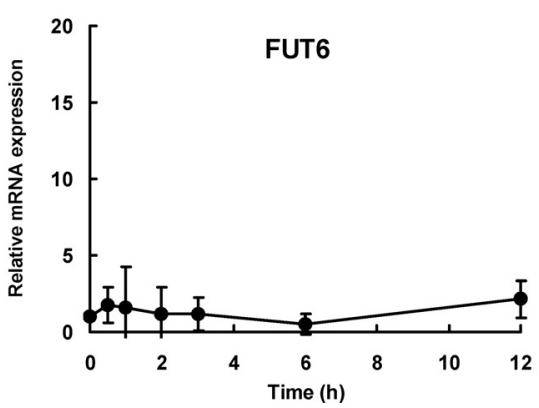

(C)

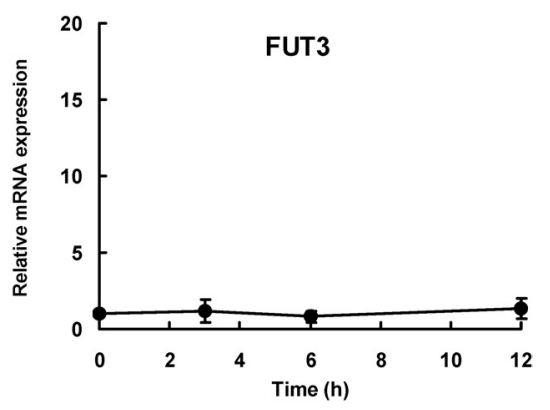

(F)

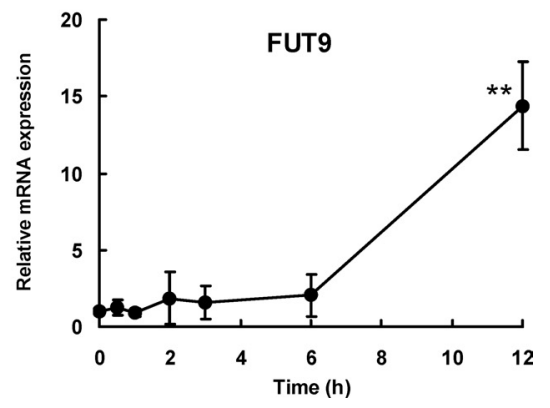

Fig. 6. Real-Time PCR for FUT mRNA in Granzyme B-Treated Jurkat Cells

Jurkat cells were pretreated with $2.0 \mu \mathrm{g} / \mathrm{ml}$ granzyme B for $4 \mathrm{~h}$ and then incubated in medium containing $10 \%$ FBS for 0 to $12 \mathrm{~h}$ at $37{ }^{\circ} \mathrm{C}$. Total RNA extracted from Jurkat cells was reverse-transcribed into cDNA. (A) FUT mRNA/ GAPDH mRNA at $0 \mathrm{~h}$ : Levels of FUT mRNA in the cells after a $4 \mathrm{~h}$ treatment with BioPORTER ${ }^{\circledR}$ alone were normalized by the levels of GAPDH mRNA. (B-F) FUT mRNA/ GAPDH mRNA at 0 to $12 \mathrm{~h}$ : Levels of FUT1 and FUT2 (B), FUT3 (C), FUT4 (D), FUT 6 (E), and FUT9 (F) mRNAs 0 to $12 \mathrm{~h}$ after a $4 \mathrm{~h}$ treatment with granzyme B were normalized by the levels of GAPDH mRNA and FUT mRNA/ GAPDH mRNA were corrected by the value at $0 \mathrm{~h}$ as 1.0 . The results represent the means \pm S.D. $(n=3) . * p<0.05, * * p<0.01$.

was nearly eliminated by the caspase 3 inhibitor but was partially suppressed by the inhibitors of caspase 8 and not affected by the inhibitors of caspase 9 . These results indicate that caspase 3 activation by granzyme B plays a key role in the induction of apoptosis and enhanced cell surface expression of Lewis $\mathrm{X}$ and $\mathrm{Y}$ antigens. Also, activation of caspase 8 and 9 plays partial and minor roles, respectively, in the activation of caspase 3 during granzyme B-induced Jurkat cell apoptosis. However, the inhibitory effect on granzyme B of Ac-IETD-CHO that we used as a caspase8 inhibitor has been reported. ${ }^{18)}$ It was considered that the inhibitory effects on granzyme B under this condition have an insignificant effect, since Ac-IETD-CHO did not affect the cell viability. This inhibitory effect of Ac-IETD-CHO on granzyme B may cause a partial suppression of the increases in the expression of Lewis $\mathrm{X}$ antigen.

Genes encoding six forms of $\alpha 1-3 / 4$ FUT have been cloned, namely, FUT3, ${ }^{19}$ FUT4, ${ }^{20)}$ FUT5, ${ }^{21)}$ FUT6, ${ }^{21)}$ FUT7, ${ }^{22)}$ and FUT9. ${ }^{23)}$ FUT3, FUT4, FUT5, FUT6, and FUT9 can synthesize Lewis Y antigen on the H-type-2 structure Fuc $\alpha 1-2 \mathrm{Gal} \beta 1-4 \mathrm{GlcNAc}$, whereas type- $2 N$-acetyllactosamine $\mathrm{Gal} \beta 1-4 \mathrm{GlcNAc}$ is a better substrate for synthesis of Lewis X by FUT4, FUT6, and FUT9, and type-1 Gal $\beta 1$ $3 \mathrm{GlcNAc}$ is a better substrate for the synthesis of Lewis A Gal $\beta 1-3$ (Fuc $\alpha 1-4)$ GlcNAc by FUT3 and FUT5. ${ }^{24)}$ FUT7 can synthesize only sialyl-Lewis X antigen. FUT9 can preferentially fucosylate the distal GlcNAc residue of the poly- $N$ acetyllactosamine chain, whereas FUT3, FUT4, FUT5, and FUT6 preferentially fucosylate the inner GlcNAc residue. $^{25,26)}$ Competitive RT-PCR shows that FUT4 tran- scripts are ubiquitously expressed in peripheral blood cells and that FUT9 transcripts are expressed in granulocytes but not in peripheral monocytes, HL-60, U937, or Jurkat cells. ${ }^{27)}$

Of the various FUT genes, we found that Jurkat cells prominently expressed FUT4 mRNA, moderately expressed FUT1, FUT2, FUT3, and FUT6 mRNA, and scarcely expressed FUT9 mRNA. Moreover, FUT4 and FUT9 mRNA expression was distinctly up-regulated in Jurkat cells $3 \mathrm{~h}$ and $12 \mathrm{~h}$ after granzyme B treatment respectively, whereas granzyme B treatment did not affect the expression of other FUT mRNAs. These results indicate that caspase 3 activation leads to the up-regulation of FUT4 and FUT9 mRNA expression, which increases the cell surface expression of Lewis $\mathrm{X}$ and $\mathrm{Y}$ antigens. Thus, it appears that FUT4 plays a principal role and FUT9 a minor role in the granzyme B-induced synthesis of Lewis X and Y antigens in Jurkat cells.

We have previously shown that during anti-Fas antibodyinduced Jurkat cell apoptosis, there is a large increase in the cell surface expression of Lewis $\mathrm{X}$ and $\mathrm{Y}$ antigens that is suppressed by both caspase 3 and 8 inhibitors. ${ }^{17)}$ Although the anti-Fas antibody and granzyme B resulted in similar levels of apoptosis, granzyme B resulted in much less cell surface expression of Lewis $\mathrm{X}$ and $\mathrm{Y}$ antigens than the anti- Fas antibody. During apoptosis induced by both agents, there is a prominent increase in FUT4 mRNA, but, in contrast to granzyme B, the anti-Fas antibody did not cause an increase in the level of FUT9 mRNA. These results cannot be directly compared because FUT mRNA levels during anti-Fas antibody-induced apoptosis were analyzed by Northern blotting, whereas RT-PCR was used to measure the FUT mRNA levels 
during granzyme B-induced apoptosis. In addition, apoptosis induced by these two agents may involve different signaling pathways. Therefore, why there are differences in the expression of FUT4 and FUT9 mRNA remains unclear.

Previously, some reports concerning FUT4 and apoptosis have been described about adenocarcinoma cells. Akamatsu ${ }^{28)}$ has reported a predominant increase in Lewis $\mathrm{X}$ and a slight increase in Lewis $\mathrm{Y}$ due to the enhanced expression of FUT4 mRNA during interferon $\gamma$ (IFN $\gamma$ )- and anti-Fas antibody-induced apoptosis in human colon adenocarcinoma HT-29 cells. In contrast, IFN $\gamma$ alone up-regulates FUT4 mRNA in HT-29 cells, and expression of all blood group-related antigens, including Lewis $\mathrm{X}$ and $\mathrm{Y}$ antigens, are suppressed in late apoptosis. ${ }^{29)}$ IFN $\gamma$ and some chemotherapeutic drugs also up-regulate Lewis Y antigens on HT-29 cells. ${ }^{30)}$ The FUT4 gene is transcribed at two different initiation sites, resulting in long and short forms of the mRNA. Myeloid cells express high levels of the long form, whereas colon adenocarcinoma cells express high levels of the short form. ${ }^{31)}$ In addition, the transcription factor Elk-1 has been shown to enhance the expression of FUT4 mRNA. ${ }^{32}$ Furthermore, anti-Fas antibody and granzyme B are expected to cause different patterns of protein phosphorylation and cleavage. Further studies are necessary to clarify the differences in how these two agents induce apoptosis.

In conclusion, our results show that FUT4 mRNA is upregulated during granzyme B-induced apoptosis. This occurs through signaling downstream of caspase 3 activation and results in increased cell surface expression of Lewis $\mathrm{X}$ and $\mathrm{Y}$ antigens. Although it was considered that Lewis $\mathrm{X}$ and $\mathrm{Y}$ antigens would participate in the dynamic process of apoptosis, the role of the increased expression of Lewis $\mathrm{X}$ and $\mathrm{Y}$ antigens during apoptosis remains unclear. Since Lewis $\mathrm{X}$ and Lewis $\mathrm{Y}$ antigens bind to C-type lectin in phagocyte, such as dendritic cell-specific ICAM-3-grabbing nonintegrin (DC-SIGN) ${ }^{33)}$ Lewis $\mathrm{X}$ and Lewis $\mathrm{Y}$ antigens would thus participate in the phagocytic clearance of apoptotic cells. The biological significance of Lewis X and LewisY antigens during apoptosis should be clarified by our findings and future studies.

Acknowledgements The authors thank Dr. Akiyoshi Taniguchi for technical suggestions and helpful comments. This work was supported in part by the "Open Research Center" Project from the Ministry of Education, Culture, Sports, Science and Technology (MEXT).

\section{REFERENCES}

1) Edwards K. M., Davis J. E., Browne K. A., Sutton V. R., Trapani J. A., Immunol. Cell Biol., 77, 76-89 (1999).

2) Screpanti V., Wallin R. P., Grandien A., Ljunggren H. G., Mol. Immunol., 42, 495-499 (2005).

3) Guma M., Angulo A., Lopez-Botet M., Curr. Top. Microbiol. Immunol., 298, 207-223 (2006).

4) Kam C. M., Hudig D., Powers J. C., Biochim. Biophys. Acta, 1477, $307-323$ (2000)
5) Lord S. J., Rajotte R. V., Korbutt G. S., Bleackley R. C., Immunol. Rev., 193, 31-38 (2003).

6) Waterhouse N. J., Sedelies K. A., Trapani J. A. Immunol. Cell. Biol., 84, 72-78 (2006).

7) Metkar S. S., Wang B., Ebbs M. L., Kim J. H., Lee Y. J., Raja S. M., Froelich C. J., J. Cell Biol., 160, 875-885 (2003).

8) Atkinson R. V., Barry M., Darmon A. J., Shostak I., Turner P. C., Moyer R. W., Bleackley C., J. Biol. Chem., 273, 21261-21266 (1998).

9) Medema J. P., Toes R. E., Scaffidi C., Zheng T. S., Flavell R. A., Melief C. J., Peter M. E., Offringa R., Krammer P. H., Eur. J. Immunol., 27, 3492-3498 (1997).

10) Barry M., Heibein J. A., Pinkosky M. J., Lee S. F., Moyer R. W., Green D. R., Bleackley R. C., Mol. Cell Biol., 20, 3781-3794 (2000).

11) Alimonti J. B., Shi L., Baijal P. K., Greenberg A. H., J. Biol. Chem., 276, 6974-6982 (2001).

12) Froelich C. J., Orth K., Turbov J., Seth P., Gottlieb R., Babior B., Shah G. M., Bleackley R. C., Dixit W. M., Hanna W., J. Biol. Chem., 271, 29073-29079 (1996).

13) Metkar S. S., Wang B., Aguilar-Santelises M., Raja S. M., UhlinHansen L., Podack E., Trapani J. A., Froelich C. J., Immunity, 16, 417-428 (2002).

14) Kurschus F. C., Kleinschmidt M., Fellows E., Dornmair K., Rudilph R., Lilie H., Jenne D. E., FEBS Lett., 562, 87-92 (2004).

15) Shi L., Yang X., Froelich C. J., Greenberg A. H., Method Enzymol., 322, 125-142 (2000).

16) Zelphati O., Wang Y., Kitada S., Reed J. C., Felgner P. L., Corbeil J., J. Biol. Chem., 276, 35103-35110 (2001).

17) Azuma Y., Ito M., Taniguchi A., Matsumoto K., Biochim. Biophys. Acta, 1672, 157-163 (2004).

18) Thornbery N. A., Rano T. A., Peterson E. P., Rasper D. M., Timkey T., Garcia-Calvo M., Houtzager V. M., Nordstorm P. A., Roy S., Vaillancourt J. P., Chapman K. T., Nicholson D. W., J. Biol. Chem., 272, 17907-17911 (1997).

19) Kukowska-Latallo J. F., Larsen R. D., Nair R. P., Lowe J. B., Genes Dev., 4, 1288-1303 (1990).

20) Lowe J. B., Kukowska-Latallo J. F., Nair R. P., Larsen R. D., Marks R. M., Macher B. A., Kelly R. J., Ernst L. K., J. Biol. Chem., 266, 17467-17477 (1991).

21) Weston B. W., Smith P. L., Kelly R. J., Lowe J. B., J. Biol. Chem., 267, 24575-24584 (1992).

22) Natsuka S., Gersten K. M., Zenita K., Kannagi R., Lowe J. B., J. Biol. Chem., 269, 16789-16794 (1994).

23) Kaneko M., Kudo T., Iwasaki H., Ikehara Y., Nishihara S., Nakagawa S., Sasaki K., Shiina T., Inoko H., Saitou N., Narimatsu H., FEBS Lett., 452, 237-242 (1999).

24) Cailleau-Thomas A., Coullin P., Candelier J. J., Balanzino L., Mennesson B., Oriol R., Mollicone R., Glycobiology, 10, 789-802 (2000).

25) Nishihara S., Iwasaki H., Kaneko M., Tawada A., Ito M., Narimatsu H., FEBS Lett., 462, 289-294 (1999).

26) Toivonen S., Nishihara S., Narimatsu H., Renkonen O., Renkonen R., Glycobiology, 12, 361-368 (2002).

27) Nakayama F., Nishihara S., Iwasaki H., Kudo T., Okubo R., Kaneko M., Nakamura M., Karube M., Sasaki K., Narimatsu H., J. Biol. Chem., 276, 16100-16106 (2001).

28) Akamatsu S., Yazawa S., Zenita K., Matsumoto H., Tachikawa T., Kannagi R., Glycoconj. J., 13, 1021-1029 (1996).

29) Rapoport E., Pendu J. L., Glycobiology, 9, 1337-1345 (1999).

30) Flieger D., Hoff A. S., Sauerbruch T., Schmidt-Wolf I. G., Clin. Exp. Immunol., 123, 9-14 (2001).

31) Taniguchi A., Suga R., Matsumoto K., Biochem. Biophys. Res. Commun., 273, 370-376 (2000).

32) Withers D. A., Hakomori S. I., J. Biol. Chem., 275, 40588-40593 (2000).

33) Aarnoudse C. A., Garcia Vallejo J. J., Saeland E., van Kooyk Y., Curr. Opin. Immunol., 18, 105-111 (2006). 